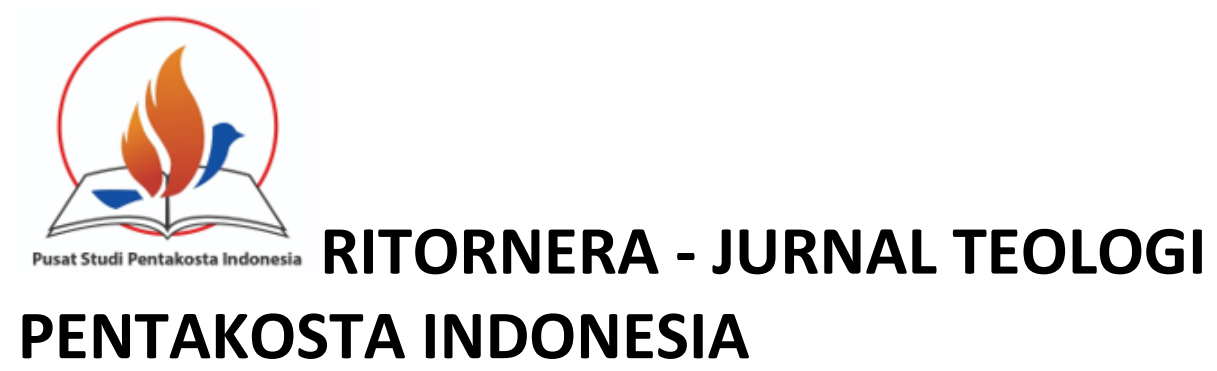

Vol. 1, No. 2, August 2021

Available at: pspindonesia.org

\title{
Kajian Teologis Konsep Hidup Tekun Menurut Surat Yakobus 1:2-8 dan Aplikasinya Bagi Kehidupan Orang Percaya Pada Masa Kini
}

\author{
Stefanus Agus Budi Yanto ${ }^{1}$ \\ stefanus2013@gmail.com \\ Paulus Kunto Baskoro 2 \\ paulusbaskoro1177@gmail.com
}

\begin{abstract}
The life of a believer is a process that continues until the end of his life. The process of living is an important part for every believer. Living like Jesus is the ultimate goal for every believer. However, there are many who believe that their lives are not optimal in following Jesus. Even though they have been to church for a long time and have even served, manu Chirstians when facing life's challenges, sturglles, problems and suffering, are quisker to grumble and leave the Lord Jesus. This is a sign of the spiritual immaturity of the believer. Not because believers do not understand, but not serious in fllowing Jesus. Perseverance means that in all situations and circumstances, believers are given the ability to perverse and try to countinue without giving up on holding faith in Jesus by becoming trus deors of the Word. This is lifestyle or attiude of life that does not easily give up or lose in the face of every problem and struggle and even suffering because of following Jesus. In order to abtain accurate and accountable data, in this study the authords used the method of writing descriptive literature. Is is hoped that with this writing, every believer will remain faithful in following Jesus even though they face all kinds of challenges, life strunggles and even suffering. The purpose of this writing is Frist, every believer remains diligent in following Jesus, despite facing many challenges; Second, believers remain a blessing, despite challenges; Third, every believer wind in the face of all challenges and God's name is glorified.
\end{abstract}

Keywords: Perseverance, Spiritual Adult, Believer

\section{Abstrak}

Kehidupan orang percaya merupakan proses yang terus berjalan sampai akhir hidupnya. Proses hidup merupakan bagian penting bagi setiap orang percaya. Hidup menjadi serupa dengan Yesus adalah tujuan utama bagi setiap orang percaya. Namun banyak ditemukan percaya yang hidupnya tidak maksimal dalam mengikuti Yesus. Meskipun sudah lama ke gereja bahkan sudah melayani, namun banyak orang Kristen ketika menghadapi tantangan hidup, pergumulan, persoalan dan menderita, lebih cepat bersunggut-sungut dan meninggalkan Tuhan Yesus. Ini adalah sebuah tanda ketidakdewasaan rohani orang percaya. Bukan karena orang percaya tidak memahami, namun ketidakseriusan dalam mengikut 
Yesus. Tekun artinya didalam segala situasi dan keadaan orang percaya diberikan kemampuan untuk tetap bertahan dan berusaha terus tanpa putus memegang iman percaya kepada Yesus dengan menjadi pelaku Firman yang sungguh. Ini adalah sebuah gaya hidup atau sikap hidup yang tidak mudah menyerah atau kalah dalam menghadapi setiap persoalan dan pergumulan bahkan penderitaan karena mengikut Yesus. Untuk mendapatkan data-data yang akurat dan dapat dipertanggungjawabkan, dalam penelitian ini penulis menggunakan metode penulisan deskriptif literatur. Harapannya dengan tulisan ini, setiap orang percaya tetap setia dalam mengikut Yesus meskipun menghadapi segala macam tantangan, pergumulan hidup bahkan menderita sekalipun. Tujuan penulisan ini adalah Pertama, setiap orang percaya tetap tekun mengikut Yesus, meskipun menghadapi banyak tantangan; Kedua, orang percaya tetap menjadi berkat, meskipun menghadapi tantangan; Ketiga, setiap orang percaya menang menghadapi segala tantangan dan nama Tuhan dipermuliakan.

Kata kunci: Tekun, Dewasa Rohani, Orang Percaya

\section{PENDAHULUAN}

Hidup bertekun dalam segala hal menjadi bagian penting dalam kehidupan setiap orang percaya. Kitab Yakobus menjadi acuan untuk dasar teologis setiap orang percaya bertumbuh makin dewasa dalam Kristus. Kitab Yakobus adalah sebuah kitab yang menekankan mengenai perbuatan manusia sebagai buah dari iman Kristen. Buah iman adalah bukti kehidupan lahir baru orang percaya. ${ }^{1}$ Kitab Yakobus tidak bisa lepas dari pengamatan akan kehidupan umat Tuhan yang ada pada waktu itu, dimana masalah dan tekanan hidup yang orang percaya hadapi di masa perantauan. Melihat permulaan dan penutupan dari kitab ini dapat dilihat dalam memberikan dorongan dan nasihat kepada jemaat Tuhan yang ada di perantauan. Baxter menyatakan maksud menyatakan memberikan nasihat dan penghiburan kepada orang Kristen yang mengalami pencobaan, kesusahan dan hukuman karena iman Kristen. ${ }^{2}$ Jadi dapat diambil suatu pengertian bahwa tanpa adanya ketekunan dari dalam diri orang Kristen yang ada diperantauan, sangat sulit bagi orang percaya untuk menghadapi

\footnotetext{
${ }^{1}$ Jimmy Kurniawan, “Kajian Eksegetikal Tentang Kelahiran Baru Menurut Yohanes 3:1-8,” Jurnal Teologi Gracia Deo 1, no. 1 (2018): 1-13.

2 J. Sildow Baxter, Menggali Isi Alkitab. Jil. 4 (Jakarta: Yayasan Komunikasi Bina Kasih/OMF, 1995).

Copyright(C2021; Ritornera - Jurnal Teologi Pentakosta Indonesia |38
} 
masalah dan tantangan yang saat itu ada. Ketekunan merupakan proses disepanjang kehidupan. $^{3}$

Kedewasaan rohani sangat vital dalam kehidupan orang percaya. Charles Swindoll dalam bukunya Maju Tiga Langkah Mundur Dua Langkah, memberikan pernyataan sebagai berikut: ketekunan adalah satu proses yang disebut sebagai osmosa rohani, dimana setiap orang percaya mendengarkan dan menyerap kebenaran Alkitab lalu membiarkan kebenaran itu meresap jauh ke dalam hidup dan lubuk hati, dimana sikap dan keputusan dibuat. Lalu bila keadaan membutuhkan suatu reaksi supranatural, maka Roh Kudus yang ada dalam diri setiap orang percaya akan menggunakan simpanan itu untuk memberikan kekuatan dan ketetapan hari di dalam mengatasi kesulitan-kesulitan. Keadaan ini berlaku untuk segala macam kesukaran. ${ }^{4}$ Pengenalan akan kebenaran saja tidak cukup menjadi dewasa tanpa adanya penerapan, maka kebenaran tidak akan dapat memecahkan satu persoalanpun. ${ }^{5}$ Kedewasaan orang percaya diperoleh melalui ketekunan yang murni dan sungguh-sungguh dengan menerapkan apa yang didengar dan ditaatinya. ${ }^{6}$ Tujuan penelitian ini adalah menemukan arti ketekunan dalam Yakobus 1:2-8 dan aplikasinya bagi orang percaya masa ini yaitu adanya orang percaya yang sudah lama mengikuti Yesus bahkan terlibat dalam kepengurusan serta pelayanan, namun ketika menghadapi tantangan hidup yang berat, selalu menyalahkan Tuhan, mundur dari pelayanan, mundur tidak setia ibadah bahkan ada yang meninggalkan Tuhan Yesus. Diharapkan dengan penulisan ini, memberikan kekuatan kepada setiap orang percaya untuk tetap bertekun mengikut Yesus, melayani Yesus dan setia kepada Yesus, apapun yang terjadi dalam kehidupan.

\footnotetext{
${ }^{3}$ Kevin Humble, Diktat Pastoral Konseling (Yogyakarta: STT Injili Indonesia, 2000), 21.

${ }^{4}$ Charles Swindoll, Maju Tiga Langkah Mundur Dua Langkah (Surabaya: YAKIN, 2000), 45.

${ }^{5}$ Swindoll, Maju Tiga Langkah Mundur Dua Langkah.

${ }^{6}$ Ibid.

Copyright $\bigcirc 2021$; Ritornera - Jurnal Teologi Pentakosta Indonesia |39
} 


\section{METODE}

Dan untuk mendapatkan data-data yang akurat dan dapat dipertanggungjawabkan, dalam penelitian ini metode deskritif literatur. ${ }^{7}$ Dengan metode ini penulis mempelajari kajian teologis konsep hidup bertekun menurut Surat Yakobus 1:2-8 dan aplikasinya bagi kehidupan orang percaya pada masa kini. Penulis menggali kebenaran-kebenaran secara studi teologis berdasarkan Surat Yakobus 1:2-8. Penulis juga melakukan bukti dasar penafsiran terhadap hast dengan metode penfasiran hermeneutik yaitu kontekstual, literal, gramatikal, historikal, tujuan penulis, teologis dan kesimpulan. Dan pemahaman ini akan diimplementasikan bagi orang percaya serta gereja Tuhan, sehingga memiliki dasar teologi yang kokoh, serta iman kepada Yesus lebih kokoh dan kehidupan orang percaya makin dewasa secara maksimal. ${ }^{8}$

\section{PEMBAHASAN}

Hidup “bertekun” menurut Surat Yakobus 1:2-8 dan aplikasinya bagi kehidupan orang percaya pada masa kini dalam penulisan ini merupakan pembahasan yang sangat penting, apalagi melihat tantangan yang dihadapi orang percaya masa kini yang tidak jauh berbeda dengan apa dihadapi oleh orang percaya di zaman Yakobus. Perubahan zaman pasti terjadi serta kemajuan ilmu dan tehnologi juga akan berkembang, namun kehidupan esensi orang percaya untuk makin bertekun seharusnya tidak terjadi degradasi. Justru seharusnya makin lama mengikut Yesus, makin hidup bertekun, sehingga hikmat Tuhan selalu nyata. ${ }^{9}$ Untuk mendapatkan pemahaman yang utuh tentang hidup bertekun, maka perlu dipahami dahulu

\footnotetext{
${ }^{7}$ Sonny Eli Zaluchu, "Strategi Penelitian Kualitatif Dan Kuantitatif Di Dalam Penelitian Agama," Evangelikal: Jurnal Teologi Injili dan Pembinaan Warga Jemaat 4, no. 1 (2020): 28-38.

${ }^{8}$ Paulus Kunto Baskoro and Indra Anggiriati, "Keterkaitan Kedewasaan Rohani Dengan Penatalayanan Yang Maksimal Dalam Gereja Dan Dunia Market Place," LOGIA: Jurnal Teologi Pentakosta 2, no. 2 (2021): 32-51.

${ }^{9}$ Paulus Kunto Baskoro and Indra Anggiriati, "Implementasi Pemuridan Dalam Efesus 4: 11-16 Bagi Pertumbuhan Rohani Jemaat Di Masa Kini,” Sabda: Jurnal Teologi Kristen 2, no. 1 (2021): 242-265.

Copyright(C2021; Ritornera - Jurnal Teologi Pentakosta Indonesia |40
} 
tentang Surat Yakobus dan menganalisa prinsip-prinsip hidup bertekun dalam Surat Yakobus 1:2-8 kemudian diaplikasikan dalam kehidupan sehari-hari.

\section{Landasan Dasar Surat Yakobus}

Surat Yakobus adalah surat yang berfokus kepada bagaimana orang percaya menjalankan kehidupan sebagai orang percaya atau lebih kepada sebuah hubungan praktis dari kebenaran Firman Tuhan. Yakobus menyatakan bahwa yang terpenting bagaimana setiap orang percaya sanggup mengatasi setiap tantangan hidup dan menjadi pribadi yang kaut serta makin dewasa dalam Kristus (1:2-11), hidup kuat menghadapi godaan (1:12-18), orang percaya yang serius menjadi pelaku Firman Tuhan, bukan hanya pendengar saja $(1: 19-27) .{ }^{10}$ Dibawah ini adalah landasan dasar secara garis besar Surat Yakobus untuk akhirnya mendapatkan prinsip-prinsip standart kehidupan Kristen yang memiliki kehidupan bertekun dalam Kristus.

\section{Latar Belakang Surat Yakobus}

Surat Yakobus menjadi bagian dalam 27 kitab dalam Perjanjian Baru. Penulis dari Surat Yakobus dinyatakan dalam 2 bukti, yaitu bukti secara internal dan bukti secara eksternal dan menunjukkan keabsahannya. ${ }^{11}$ Pembukaan Surat Yakobus 1:1 sudah disebutkan secara jelas siapa penulis Surat Yakobus, yaitu Yakobus sendiri. Namun yang menjadi pertanyaan adalah siapa Yakobus dalam nas ini. Dalam Perjanjian Baru ada empat orang yang bernama Yakobus, diantaranya Yakobus anak Zebedeus dan kakak Yohanes (Mark. 1:9), Yakobus anak Alfeus (Mark. 3:18), Yakobus ayah Yudas (Luk. 6:16) dan Yakobus adik Yesus (Gal. 1:9). Bukti internal menyatakan secara jelas fokus kepada Yakobus adik dari Tuhan Yesus, yang juga diyakini oleh para pakar masa lampau yang menjadi bukti secara eksternal. Penafsir

${ }^{10}$ Donald C. Stamps, Alkitab Penuntun Hidup Berkelimpahan (Malang: Gandum Mas, 2000).

${ }^{11}$ Demsy Jura, "Mengenal Penulis Kitab Yakobus Dan Pengajarannya," Jurnal Shanan 1, no. 1 (2017): 158-178.

Copyright(C2021; Ritornera - Jurnal Teologi Pentakosta Indonesia |41 
jelas menyatakan penulis Surat Yakobus adalah Yakobus adik Yesus sesuai dengan beberapa hal dalam tradisi Yahudi, sebab Yakobus adik Yesus sebagai salah satu tokoh gereja mulamula. ${ }^{12}$ Thenny juga menyatakan hal yang sama bahwa penulis kitab Yakobus adalah Yakobus adik Tuhan Yesus yang menjadi pemimpin sidang di Yerusalem (Kis. 15). ${ }^{13}$ Berdasarkan banyak pandangan secara eksternal, Yakobus adalah pribadi yang saleh, sangat memperhatikan peraturan hidup dan suka hidup dalam doa serta sungguh-sungguh dalam Tuhan. ${ }^{14}$ Yakobus mati martir pada tahun $62 \mathrm{M}$ oleh orang-orang Yahudi yang memusuhinya. ${ }^{15}$ Tahun penulisan Surat Yakobus dinyatakan pada tahun 40-45 Masehi. ${ }^{16}$ Sebab dalam tulisan Yakobus tidak ditemukan konsep tentang jatuhnya Yerusalem, perselisihan Yahudi dan non Yahudi juga tidak dinyatakan.

\section{Tujuan Penulisan Surat Yakobus}

Surat Yakobus termasuk surat umum kepada pada mulanya dialamatkan kepada sidang pembaca yang lebih luas daripada jemaat lokal, hal ini bisa dilihat dalam "salam kepada keduabelas suku diperantauan ...” (1:1;2:19-21). Hal ini menunjukkan bahwa surat ini pada umumnya ditujukan kepada orang-orang Kristen yang tinggal di luar Yerusalem. Kemungkinan penerima surat ini termasuk orang-orang yang pertama bertobat di Yerusalem, setelah Stefanus mati sahid mereka terserak oleh penganiayaan (Kis. 8:1). Sangat bisa diketahui bahwa dalam Surat Yakobus jarang pembicaraan tentang Kristologi, karena memang kuatnya tekanan orang Yahudi menekan orang yang percaya Yesus. ${ }^{17}$ Surat Yakobus memiliki ciri khas yaitu penekanannya yang kuat pada cara hidup yang benar. Dan fokus maksud Surat Yakobus mau menyatakan bahwa setiap orang percaya yang tersebar di

\footnotetext{
${ }^{12}$ Adina Champan, Pengantar Perjanjian Baru (Bandung: Yayasan Kalam Hidup, 2000), 137.

${ }^{13}$ Merrill C. Tenney, Survei Perjanjian Baru (Malang: Gandum Mas, 1993).

${ }^{14}$ Walter M. Dunnett, Pengantar Perjanjian Baru (Malang: Gandum Mas, 2001).

${ }^{15}$ George Eldon Ladd, Teologi Perjanjian Baru, Jil. 2 (Bandung: Yayasan Kalam Hidup, 1999).

${ }^{16}$ Tafsiran Alkitab Masa Kini, Jil. 3 (Jakarta: Yayasan Komunikasi Bina Kasih/OMF, 1988).

17 Tenney, Survei Perjanjian Baru. Copyright(C2021; Ritornera - Jurnal Teologi Pentakosta Indonesia |42
} 
perantauan harus tetap sukacita dalam mengalami pencobaan, kesusahan, hukuman karena iman dalam Yesus dan menerima hikmat dari Tuhan dalam menghadapi ujian hidup dengan iman yang kokoh. ${ }^{18}$

\section{Keadaan Budaya Masyarakat Orang Yahudi}

Menyadari keadaan masyarakat orang Yahudi menjadi bagian terpenting untuk bisa memahami bahwa betapa orang percaya yang hidup di masa itu, harus berjuang dengan maksimal untuk bertahan karena iman dalam Yesus. Dari sisi budaya, berdasarkan penyelidikan dalam Surat Yakobus ada beberapa nast yang menunjukkan budaya yang berkembang di tengah kebudayaan orang Yahudi. Di dalamnya menjelaskan kuasa dari lidah yang bisa menjadi berkat sekaligus menjadi kutuk bagi orang lain, penulis Yakobus memberikan suatu ilustrasi atau gambaran tentang seekor kuda dengan kekang yang ada pada umumnya (Yak. 3:3). Gambaran dan ilustrasi mengenai kekang pada mulut kuda ini, menunjukkan akan adanya suatu kebudayaan Yahudi yaitu untuk menguasai seluruh anggota tubuh dari seekor kuda seseorang harus mengenakan sebuah kekang yang ada pada mulutnya. Sisi yang lain yang menunjukkan kebudayaan Yahudi yang diangkat dalam nast Surat Yakobus adalah dalam Yakobus 5:14. Dalam bagian ini Yakobus melihat bahwa pendekatan budaya Yahudi dengan menggunakan minyak menjadi sarana dalam mendoakan ${ }^{19}$ seperti yang nyata dalam Perjanjian Lama dalam penggunaan minyak. Penggunaan minyak dalam Perjanjian Lama sering digunakan orang Yahudi seperti untuk mengurapi seorang raja (1Sam. 10:1; 16:3; Mzm. 23:5; 89:21), sebagai persembahan kepada Allah (Kej. 28:18; 35:14). Minyak juga digunakan sebagai sarana mengobati orang sakit (Mark. 6:13; Luk. 10:34; Yak. $5: 14)$.

${ }^{18}$ Suriani Sukowati Arifin, "Hikmat Menurut Kitab Yakobus," Diligentia: Journal of Theology and Christian Education 1, no. 1 (2019): 15-24.

${ }^{19}$ Defi Ratna Sari Sihaloho, "“Fungsi Minyak Sebagai Penyembuh (Studi Eksegetis Injil Markus 6:13 Dan Surat Yakobus 5: 14)'.," Areopagus : Jurnal Pendidikan Dan Teologi Kristen 18, no. 2 (2020): 183-189.

Copyright(C2021; Ritornera - Jurnal Teologi Pentakosta Indonesia | 43 


\section{Hidup Bertekun Menurut Yakobus 1:2-8}

Dalam bagian ini penulis akan memberikan suatu eksposisi mengenai kajian teologis konsep hidup "bertekun” yang digali berdasarkan Yakobus 1:2-8. Dengan dilakukan kajian secara kontekstual, literal, gramatikal, historikal, tujuan penulis, teologis dan kesimpulan.

\section{Kontekstual}

Dalam pokok ini, akan dibahas arti "bertekun” secara kontekstual. Pembahasan akan dilakukan secara konteks dekat dan konteks jauh. Pertama, secara konteks dekat. Orang percaya mengalami pencobaan seperti pencobaan dari dunia (2:1-13), dari orang Kristen (4:1) dan berbagai masalah lainnya. Masalah-masalah yang dihadapi oleh keduabelas suku dalam perantauan, membuat Yakobus terbeban untuk memberikan penghiburan atau pengharapan bahwa dalam berbagai masalah dan ujian Tuhan mempunyai dasar rencana bagi kesempurnaan iman orang percaya. Pencobaan-pencobaan tersebut adalah ujian terhadap iman orang percaya. Melalui ujian-ujian tersebut iman orang percaya menjadi terlatih. ${ }^{20}$ Tahapan-tahapan dalam ujian tersebut adalah suatu proses dalam kesempurnaan iman. Sedangkan kesempurnaan iman adalah buah dari ketekunan (1:3-4). Pada hakekatnya iman tanpa perbuatan adalah mati. ${ }^{21}$ Artinya ketekunan adalah modal dasar untuk mencapai kedewasaan iman atau dengan perkataan lain "ketekunan" adalah salah satu tanda dari kedewasaaan yang dimiliki oleh setiap orang percaya. Yakobus mengajarkan kepada orangorang percaya yang ada diperantauan untuk berbahagia dalam pencobaan (1:2). Ungkapan untuk "tekun" oleh Yakobus diulangi lagi dalam pasal 5:4, dengan penderitaan dalam kesukaran hidup. Ketekunan dalam nast ini adalah "keteguhan hati" dalam pengharapan yang

${ }^{20}$ Todd Elefson, Diktat Kuliah Surat Yakobus (Yogyakarta: STT Injili Indonesia, 1997), 97.

${ }^{21}$ Markus Ndihi Jawamara, "Memahami Konsep Iman Dan Perbuatan Menurut Yakobus: Suatu Study Eksegesis Yakobus 2:26,” Sesawi: Jurnal Teologi Dan Pendidikan Kristen 1, no. 1 (2020): 86-98.

Copyright(C2021; Ritornera - Jurnal Teologi Pentakosta Indonesia |44 
bersifat religious dan kesetiaan pada apa yang dipercayai atau diyakini. ${ }^{22}$ Sifat tekun ini adalah hasil produk karakter Kristen dari tetap bersukacita dalam berbagai pencobaan. ${ }^{23}$

Kedua, secara konteks jauh. Dalam Perjanjian Baru, ungkapan mengenai "ketekunan” sangat penting digunakan baik dalam Injil-Injil maupun dalam surat-surat kiriman. Lukas, menggunakan istilah tersebut untuk menjelaskan bahwa setiap orang percaya yang mendengar Firman Allah harus menghasilkan buah dalam ketekunan (Luk. 8:15). Lukas juga menggunakan ungkapan lain yang memiliki kesejajaran makna dengan "ketabahan.” Lukas memakai ungkapan tersebut untuk menjelaskan bahwa orang yang tetap "bertekun" atau "tabah" dalam penderitaan (berkaitan dengan penganiayaan yang akan pasti dialami oleh orang percaya (Luk. 21:19). Rasul Paulus menggunakan ungkapan "ketekunan dalam berbagai pengertian. Dalam suratnya yang ditujukan kepada jemaat di Kolose, Paulus berkata bahwa orang percaya akan selalu diberi kekuatan untuk menanggung segala perkara dengan “tekun" dan "sabar." Ungkapan tersebut digunakan untuk menunjuk pada "tekun" dalam arti "berharap pada pengharapan iman" (band. Kol. 1:11). Dalam suratnya kepada jemaat di Tesalonika, Rasul Paulus menggunakan istilah tersebut untuk menjelaskan pengharapan iman (band. 1Tes. 1:3). ${ }^{24}$ Dan juga dalam beberapa surat lain di Perjanjian Baru mengenai "ketekunan" digunakan untuk menjelaskan "pengharapan orang percaya pada obyek imannya kepada Tuhan Yesus Kristus (band. Why. 1:9). Rasul Petrus juga menyatakan ungkapan tentang "ketekunan" untuk menjelaskan akan banyaknya masalah dalam mengikut Yesus dan

\footnotetext{
${ }^{22}$ Robert John Stone, Lectures Exegetial And Pratical On The Epistle of James (Minneapolis: Klock and Clokl Christian Publishers, 1978), 78.

${ }^{23}$ HISKIA GULO, "Konsep Pencobaan Menurut Yakobus 1:12-15," BONAFIDE: Jurnal Teologi dan Pendidikan Kristen 1, no. 2 (2020): 165-179.

${ }^{24}$ Colin Brown, The New International Dictionary of The New Testement Theology (Michigan: Zondervan Publishing House, 1976), 775. Copyright(C2021; Ritornera - Jurnal Teologi Pentakosta Indonesia | 45
} 
berbuat baik dalam penderitaan (band. 1Pet. 2:20). ${ }^{25}$ Dengan kata lain menurut Rasul Paulus "bertekun” adalah kuat dalam menderita karena iman dalam Yesus Kristus.

\section{Literal}

Secara literal, ungkapan mengenai "ketekunan" diterjemahkan sebagai "patience" oleh King James Version atau "endurance" oleh New American Standard atau "fortitude" oleh New English Bible atau "patience” oleh Jerusalem Bible. Istilah atau ungkapan tersebut berasal dari bahsa Gerika "hypomonen" yang oleh LAI diterjemahkan sebagai "ketekunan." Kunci pemahaman untuk mengerti makna ungkapan tersebut terletak pada kata sebelumnya

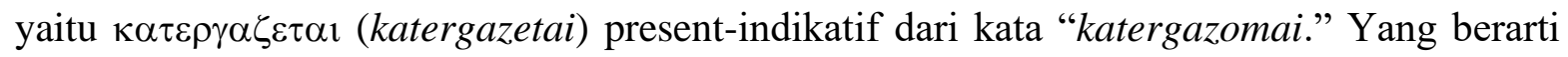
"untuk memproduk" atau "untuk melahirkan."26 Sedangkan yang dilahirkan atau diproduk

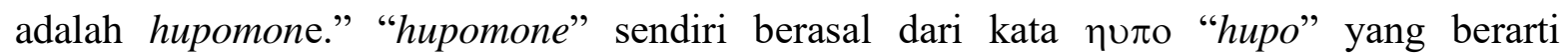
"dibawah," serta kata $\mu$ ove "mone" yang berarti "ada" atau "tinggal."27 Jika dihubungkan dengan kata sebelumnya, yaitu peirasmos yang berarti "pencobaan," maka kata tersebut mengandung arti "tinggal di bawah pencobaan atau tinggal dibawah ujian, sebagai bukti iman dalam Yesus yang realitis. ${ }^{28}$

"Cobaan" disini adalah tes atau ujian terhadap iman. Orang percaya diijinkan oleh Allah untuk mengalami ujian iman, sehingga melalui pengalaman tersebut, orang percaya atau tepatnya pengalaman orang percaya tersebut akan memproduksi atau menghasilkan yang dirindukan. ${ }^{29}$ Yakobus 1:2 adalah nast kunci dalam pembahasan ini. Ungkapan mengenai "pencobaan" menggambarkan suatu tekanan atau penganiayaan yang sangat membebani

\footnotetext{
${ }^{25}$ Brown, The New International Dictionary of The New Testement Theology.

${ }^{26}$ W.E Vine, An Expository Dictionary of New Testement Words (New Jersey: Old Tappan, 1980), 167.

27 Vine, An Expository Dictionary of New Testement Words.

${ }^{28}$ Johan Djuandy, "Revisiting the So-Called Contradiction Between James and Paul on Justification," Jurnal Amanat Agung 13, no. 2 (2017): 243-283. 1981), 168.

${ }^{29}$ Frank E. Gaeblein, The Expositors Bible Comentary (Michigan: Zondervan Publishing House, 
kehidupan orang-orang Yahudi yang percaya Tuhan Yesus sebagaimana Yakobus mengalamatkan surat ini. Kata "cobaan" atau "tes" atau "ujian" adalah kata kunci dalam masalah "ketekunan" ini. Pencobaan memiliki dua arti dasar. Pertama, ujian dengan suatu tujuan. Yaitu, ujian tersebut terjadi atas ijin Tuhan atau ujian tersebut diutus Tuhan (band. Yak. 1:12; Luk. 22:28; Kis. 20:19; 1Pet. 1:6; 4:12; 2Pet. 2:9). Kedua, dengan maksud baik atau netral (band. Gal. 4:14). Ketiga, dengan berbagai sifat atau karakter. Artinya Allah berhendak untuk membawa manusia pada tindakan yang salah melalui ujian itu (band. Yak. 1:13-14; Luk. 4:13; 8:13). Ujian atau cobaan berasal dari bahasa Yunani dari akar kata “dokime." Artinya, pengalaman yang mengandung dua makna. Pertama, proses pencobaan (band. 2Kor. 8:2). Kedua, akibat pencobaan (band. Rm. 5:4). ${ }^{30}$ Sedangkan ketekunan dalam Yakobus 1:3 lebih menunjukkan pada hasil dari suatu pengalaman. Hasil tersebut dipakai melalui proses berbagai tahapan untuk tetap berbahagia dalam segala pencobaan atau tabah dalam pencobaan. Proses tersebut menghasilkan ketekunan yang diharapkan oleh setiap orang percaya dalam kehidupan rohani setiap orang. ${ }^{31}$ Kesimpulan secara literal ungkapan "ketekunan" dalam nast Yakobus 1:2-8 memiliki arti sebagai karakter atau sifat orang percaya yang dihasilkan melalui proses perjuangan hidup.

\section{Gramatikal}

Secara gramatikal, letak kunci pemahaman mengenai "ketekunan" adalah pada kata "katergazetai" present-indikatif-medial dari kata "katergazomai" atau "menghasilkan." Present sebagai element dalam Bahasa Yunani memiliki fungsi sebagai kata yang

\footnotetext{
${ }^{30}$ Irving L. Jansen, James (Chicago: The Moody Bible Institude, 1971), 23.

${ }^{31}$ RVG. Tasker, The General Epistle of James, Grand Rapi. (Eerdmans Publishing Company, 1956), 40. 
menerangkan ide yang terus berlanjut atau progresif. Present adalah tensis yang bersifat linear (seperti garis panjang yang tak putus). ${ }^{32}$ Ungkapan "katergazomai" atau "menghasilkan" memiliki fungsi yang present dan costumary. Artinya ungkapan "menghasilkan" apabila dihubungkan dengan "ketekunan" maka "ketekunan" adalah sebagai buah yang berkelanjutan dari "berbahagia dalam berbagai pencobaan." Sedangkan "ketekunan" sendiri menjadi suatu sifat atau kebiasaan hidup orang yang percaya kepada Tuhan Yesus. Sedangkan "medial" menunjukkan bahwa subyek bertindak sedemikian rupa sehingga ia (subyek) mengambil bagian dalam akibat. ${ }^{33}$ Dalam nast kunci Yakobus 1:3, ungkapan "katergazomai" atau "menghasilkan" cenderung memiliki arti "refleksi." Bila dihubungkan dengan kata "ketekunan" atau "hupomone" maka medial ini memiliki makna bahwa ketekunan adalah suatu akibat atau hasil dari produk untuk tetap bersukacita dalam berbagai penderitaan. Jadi, ketekunan adalah buah yang merupakan suatu produk atau hasil yang didapat dari tindakan "tetap bersukacita." Atau lebih singkatnya, tekun adalah suatu karakter atau sifat orang percaya yang dihasilkan dari "tetap bersukacita dalam berbagai penderitaan." ${ }^{34}$ Mengenai jenis penderitaan, Yakobus tidak menyebutkan dengan rinci dalam ayat ini. Makna, secara gramatikal, "ketekunan" dalam Yakobus khususnya nast yang dibahas adalah suatu sifat atau karakter orang percaya yang merupakan buah dari pola hidup yang tetap tabah dan bersukacita dalam menghadapi segala masalah di tengah-tengah perjalanan iman kepada Tuhan Yesus (band. Yak. 5:11). Karakter atau sifat tersebut, pada akhirnya akan menghasilkan kemenangan.

\section{Historikal}

${ }^{32}$ H.E Dana \& Julius R. Mantey, A Manual Grammar of The New Testement (Toronto: Macmillan Company, 1927), 183.

${ }^{33}$ Ray Summer, Diktat Kuliah : Yang Pokok Dalam Bahasa Yunani Perjanjian (Yogyakarta: STT Injili Indonesia, 1998), 27.

${ }^{34}$ Sorta Harianja, "Bersukacitalah Senantiasa! Sekali Lagi Kukatakan, Bersukacitalah,” Jurnal Apollos (2017).

Copyright $(2021$; Ritornera - Jurnal Teologi Pentakosta Indonesia | 48 
Dalam dunia Yunani, ungkapan ketekunan mengandung pengertian "untuk berdiri di samping" atau "berdiri tetap" atau "berdiri teguh" atau "mengharapkan" atau bisa juga untuk "melahirkan" atau untuk "menderita." Hupomone berarti pengharapan atau penantian. Dalam dunia Yunani pengertian mengenai pengharapan atau penantian merupakan suatu pengharapan akan kebangkitan tubuh. Pengharapan di sini merupakan suatu keperluan yang bersifat aktif. Dalam paham Stoa, pengertian tersebut sangat penting dan menjadi satu cabang pengajaran yang disebut Andreia. ${ }^{35}$ Dalam dunia Perjanjian Lama dan Yudaisme, ungkapan ini memiliki beberapa makna: Pertama, berhubungan dengan Allah, yaitu mengandung pengertian menanti kedatangan Allah. Dihubungkan dengan LXX (Septuaginta), penggunaan kata "hupomone" dengan akusatif atau datif menunjukkan bahwa ide dalam kalimat, bukan berdiri menantang melainkan menanti. Pengertian ini digunakan untuk istilah Ibrani yang menekankan arti pengharapan dengan setia atau setia pada pengharapan (band. Ayb. 3:9; 32:4). Kata benda "hypomone" atau "tekun" dicatat dalam pengertian lain, yaitu "percaya." Ini merupakan atau ungkapan tersebut merupakan ciri-ciri kebenaran dalam Perjanjian Lama bahwa mereka menanti Allah. Allah adalah Allah yang agung yang disebut sebagai Allah Israel (Yer. 14:8), Ia juga Allah bangsa Israel (Mzm. 39:7). ${ }^{36}$ Dan puncak dari penantian tersebut terjadi pada masa eskatologi (Hab. 2:3). Orang percaya yang "tekun" sampai akhir akan diselamatkan (Dan. 12:2). Kuncinya adalah fokus kepada kesetiaan dan iman kepada Allah. Kedua, berhubungan dengan dunia, ungkapan mengenai "hypomone" berarti melahirkan ketekunan. Ungkapan tersebut mengandung pengertian berdiri teguh melawan permainan iblis. Ayub adalah contohnya manusia yang tidak dapat bertahan dalam kekuatannya sendiri (Ayb. 6:11). ${ }^{37}$ Yudaisme mengambil contoh Ayub sebagai model yang

\footnotetext{
${ }^{35}$ Mantey, A Manual Grammar of The New Testement.

${ }^{36}$ Sri Wahyuni Kusradi, "Pengenalan Akan Nama Allah Sebagai Peneguhan Iman Dalam Masa Kesesakan,” SCRIPTA: Jurnal Teologi dan Pelayanan Kontekstual 6, no. 2 (2020): 184-204.

${ }^{37}$ Gaeblein, The Expositors Bible Comentary. Copyright $(2021$; Ritornera - Jurnal Teologi Pentakosta Indonesia | 49
} 
membangun ide mengenai kekuatan dari berdiri teguh atau ketekunan. Jadi dalam Perjanjian Lama, ungkapan mengenai "ketekunan" mengandung pengertian berdiri teguh menghadapi masalah. Jika dihubungkan dengan Tuhan maka ungkapan tersebut arti kesetiaan dalam iman atau ketabahan dalam iman menanti kedatangan Tuhan. ${ }^{38}$

Dalam Perjanjian Baru, "hypomone" mengandung pengertian sebagai sikap dasar orang-orang percaya dalam Perjanjian Baru dalam gambaran yang berorientasi pada eskatologi. Istilah "hypomenein" digunakan dalam bentuk absolut untuk "mengharapkan" atau "menanti," menahan atau memikul dalam pengertian sebagai berikut: Pertama, berhubungan dengan Allah, ungkapan tersebut berarti mengharapkan, "menanti” penggunaan yang ada dalam dalam LXX (band. 2Tes. 3:5), ketekunan di sini berarti mengharapkan kedatangan Yesus Kristus. Kedua, berhubungan dengan dunia, mengandung pengertian “tabah" atau "berdiri teguh.” Dalam Injil-Injil Sinoptik, Yesus menggunakan ungkapan ini tiga kali, dalam Lukas 8:15, ungkapan tersebut mengandung pengertian sebagai "sifat" yang benar dalam diri orang percaya. Dalam Markus 13;13, ungkapan tersebut digunakan dalam "ujian" atau "tes" bagi orang percaya jika mau diselamatkan. ${ }^{39}$ Lukas 21:16, mengandung pengertian yang sama. Dalam tulisan Paulus, ungkapan "ketekunan” Paulus gunakan untuk menjelaskan sikap orang percaya. Dalam kitab Ibrani, ungkapan tersebut menggunakannya sebagai sifat tetap "tabah" dalam berbagai pencobaan. Dalam Wahyu, penulis kitab Wahyu menggunakan ungkapan tersebut untuk menjelaskan mengenai "pengharapan" akan kedatangan Tuhan Yesus. ${ }^{40}$ Berdasarkan fakta hitoris, ungkapan "ketekunan” selalu

\section{${ }^{38}$ Ibid.}

${ }^{39}$ Dr. Altin Sihombing, S.H. M.H. and Altin Sihombing, "Keselamatan Universalisme Versus Soteriologi Kristen Dalam Perspektif Alkitab," Voice of Wesley: Jurnal Ilmiah Musik dan Agama 3, no. 2 (2020): 41-53.

${ }^{40}$ Gaeblein, The Expositors Bible Comentary.

Copyright(C2021; Ritornera - Jurnal Teologi Pentakosta Indonesia |50 
digunakan berhubungan dengan sifat atau karakter orang percaya yang selalu setia dalam segala pergumulan menanti penggenapan iman yaitu kedatangan Yesus yang kedua kali.

\section{Tujuan Penulis}

Ada yang berpendapat bahwa nast Yakobus 2:2-8 yang mengemukakan masalah pencobaan berhubungan erat dengan tribulasi. ${ }^{41}$ Namun, banyak tokoh yang berpendapat lain. Tujuan Yakobus dalam menulis surat ini bukan untuk menerangkan masalah tribulasi tetapi mau menerangkan mengenai kedewasaan Kristen. ${ }^{42}$ Yang jelas Yakobus mau menguatkan orang-orang Kristen Yahudi yang berasal dari golongan bawah yang sedang mengalami penindasan dari orang-orang Yahudi dari golongan kaya. ${ }^{43}$ Ternyata bahwa orang Kristen pada masa Yakobus sudah sering menghadapi keadaan sulit. Mengenai macam-macam kesulitan, Yakobus tidak menulisnya secara rinci. Kemungkinan, orang percaya dianiaya, dihambat, kurang diterima masyarakat di sekitar mereka, difitnah, diejek, dan sebagainya, Mungkin juga orang percaya ditimpa kemiskinan $(2: 1-13 ; 5: 1-6)$, penyakit (5:14-15). Keadaan sualit seperti diatas, biasanya mengakibatkan dukacita, namun Yakobus berkata "bersukacitalah." Sebabnya adalah pengalaman pahit selalu ada artinya bagi iman, sebagai penguji iman tersebut supaya iman tersebut menjadi murni dan hasilnya adalah ketekunan. Kuncinya adalah implementasi dari iman dalam Yesus. ${ }^{44}$ Bertekun berarti memutuskan, tidak terbawa-bawa, tidak menyerah pada nasib. Dalam Alkitab, ketekunan itu bukanlah berasal dari kekuatan atau dari keberanian manusia sendiri, melainkan pengharapan $(1: 12 ; 5: 11 ; \mathrm{Rm}$. 5:3-4; 1Pet. 1:6-7; Kol. 1:11). Ketekunan bukanlah sesuatu yang pasif, namun sebuah

\footnotetext{
${ }^{41}$ W.E Vine, The Bible Self Explained A Commentary Wholy Biblical (Chicago: Moody Press, 1977), 2183.

42 John F. Walvoord \& Roy B. Zuck, The Bible Knowleadge Commentary (Chicago: Victor Books, 1983), 820 .

${ }^{43}$ Ladd, Teologi Perjanjian Baru, Jil. 2.

${ }^{44}$ Samuel Julianta Sinuraya, M.Th, "Makna Dibenarkan Oleh Iman Dan Perbuatan Menurut Yakobus 2:14-26," CARAKA: Jurnal Teologi Biblika dan Praktika 1, no. 2 (2020): 199-210.

Copyright (C2021; Ritornera - Jurnal Teologi Pentakosta Indonesia |51
} 
pengharapan yang dinamis. Harapan tersebut menjadi semakin kuat lagi, jikalau iman yang diuji menjadi tekun. Ketekunan tersebut harus menjadi buah yang matang. Yakobus menekankan bahwa ketekunan bukanlah sikap yang insidental. Jadi ketekunan tersebut haruslah berisikan pekerjaan sempurna. ${ }^{45}$ Itulah tujuan Yakobus mengemuakan "ketekunan" supaya orang percaya menjadi sempurna dalam iman, yang berarti berbuat menurut kehendak Allah.

Teologis

Allah memiliki tujuan dalam rencana-Nya, orang percaya sangat susah atau bahkan tidak dapat memahami hal tersebut. Yakobus dalam nast ini berbicara mengenai sikap hati terhadap masalah atau dalam menghadapi masalah. Ini dapat dimengerti dalam ungkapan "bahagia" yang mengambil bentuk aorist yang menekankan bahwa "sukacita" atau "bahagia" adalah hasil dari pekerjaan di masa lampau yaitu menghadapi cobaan-cobaan. Dalam Ibrani 12, dapat dilihat salah satu metode Allah dalam mengerti kedewasaan rohani orang percaya, secara literal memiliki arti "menguji anak." ${ }^{46}$ Allah berkata, bahwa tidak ada alasan untuk tidak ikut menderita, namun pada saat orang percaya menderita alasan terbaik adalah "Allah turut bekerja dalam segala sesuatu untuk mendatangkan kebaikan bagi semua orang yang mengasihi-Nya” (Rm. 8:28). Secara teologis, nats yang dibahas sangat berkaitan dengan berbagai masalah teologia, yaitu pertama, berhubungan karakter Kristen, alasan panggilan untuk tetap bersukacita adalah sangat sederhana; bahwa tanpa "ujian" atau "tes" maka iman tidak akan menghasilkan suatu karakter atau sifat yang teruji seperti yang diharapkan oleh

${ }^{45}$ D.S.J.J Guning, Tafsiran Alkitab Surat Yakobus (Jakarta: BPK Gunung Mulia, 1984), 32.

${ }^{46}$ Mariduk Tambun and Adi Putra, "Kajian Teologis Terhadap Markus 10:17-27," Jurnal Luxnos 5, no. 1 (2021): 27-36.

Copyright(C2021; Ritornera - Jurnal Teologi Pentakosta Indonesia |52 
Yesus Kristus serta bagian setia menderita karena Yesus. ${ }^{47}$ Para pembaca surat ini harus memahami bahwa "ujian" dan "tes" sangat diperlukan dalam perjalanan iman Kristen. Melalui ujian-ujian, iman orang percaya makin dibangun sehingga menghasilkan dan memproduksi katakter tekun. ${ }^{48}$ Kedua, berhubungan dengan pengharapan akan kedatangan Yesus. Ketekunan dalam berbagai pencobaan adalah pondasi untuk mematangkan rohani namun juga sebagaid asar pengharapan iman akan kedatangan Tuhan Yesus untuk kedua kali. Jadi, berdasarkan berbagai fakta dalam prinsip-prinsip penelitian, salah satu tanda bagian yang terpenting dalam kehidupan orang percaya menurut Yakobus 2:2-8 yaitu ketekunan. Ketekunan disini adalah suatu sifat atau karakter yang menjadi pola hidup dalam kehidupan orang percaya, sehingga membuat orang tersebut mampu bertahan dalam berbagai penderitaan dan kesukaran hidup yang menghampiri kehidupan orang tersebut. Jadi, orang yang memiliki rohani yang dewasa memiliki ciri bahwa hidupnya selalu dalam ketekunan. Serta bersukacita atas segala permasalahan dan pencobaan yang dialami. Oleh karena itu, ketekunan adalah ciri orang yang rohaninya sudah dewasa serta hidupnya selalu berfokus kepada Tuhan menuju kepada kesempurnaan ilahi. ${ }^{49}$

\section{Aplikasi Hidup Bertekun Bagi Setiap Orang Percaya di Masa Kini}

Aplikasi yang sangat jelas dalam bagian ini adalah setiap orang percaya harus hidup dalam ketekunan yang sungguh dalam Yesus. Ini adalah bukti yang nyata sebagai orang Kristen yang sejati dan murid Yesus. Sebagai gereja Tuhan dan bagian dalam komunitas gereja Tuhan secara universal menyatakan bahwa segala sesuatu yang terjadi tidak pernah luput dari pemandangan Allah. Semuanya ada dalam kendali Allah, jadi percaya dalam segala sesuatu yang dihadapi orang percaya, pasti Tuhan punya rencana dan Tuhan dan menolong

\footnotetext{
${ }^{47}$ Warseto Freddy Sihombing, "Penderitaan Orang Percaya Dalam Surat 1 Petrus," KERUGMA: Jurnal Teologi dan Pendidikan Agama Kristen (2019).

${ }^{48}$ Tasker, The General Epistle of James.

${ }^{49}$ Casey Treat, Pembaharuan Pikiran (Jakarta: Yayasan Pekabaran Injil Immanuel, 1989), 135. Copyright(C2021; Ritornera - Jurnal Teologi Pentakosta Indonesia |53
} 
serta melakukan mujizat yang luar biasa. Seringkali sebagai orang percaya, pencobaan, keadaan sulit, tantangan, tekanan dan masalah hidup tidak dapat dihindarkan. Suatu keadaan yang sebenarnya tidak pernah diinginkan dan bahkan tidak dinantikan akan datang dalam kehidupan orang percaya.

Namun posisi orang percaya sebagai anak Allah yang telah ditebus dengan darah Kristus, harus memiliki sikap hidup yang tekun dalam mengikut Yesus. Tantangan, pencobaan dan segala permasalahan tidak menjadi penghambat untuk setiap orang percaya memiliki hidup yang berkemenangan. ${ }^{50}$ Yaitu suatu kemenangan, bukan tanda kekalahan orang percaya, yang memberikan dampak bagi sesama. ${ }^{51}$ Dan setiap orang percaya harus sadar serta yakin, segala sesuatu yang terjadi, asal orang percaya tetap bertekun, pasti akan mengalami jalan keluar serta solusi dari setiap masalah yang dihadapi. Semua yang terjadi untuk menguji iman setiap orang percaya untuk bisa melihat kuasa Tuhan dinyatakan, Roh Kudus akan memberikan kekuatan dan penghiburan secara sempurna. ${ }^{52}$ Kehidupan yang penuh ketekunan harus menjadi dasar penting dalam segala aspek kehidupan orang percaya. Dimana setiap orang percaya jika mau kuat dalam kehidupannya menghadapi segala tantangan kehidupan, yaitu tekun berdoa, tekun membaca Alkitab, tekun menjadi pelaku Firman Tuhan, tekun beribadah, tekun berkorban, tekun menjalin hubungan dengan orang percaya lainnya dan tekun dalam melayani Tuhan. Sehingga apa yang dilakukan dapat

\footnotetext{
${ }^{50}$ Peniel C D Maiaweng, "Kajian Biblika Tentang Pencobaan Menurut Yakobus 1: 1-18 Dan Implikasinya Dalam Kehidupan Orang Percaya,” Repository Skripsi Online 1, no. 1 (2019): 32-40.

${ }^{51}$ Sri Lina Betty Lamsihar Simorangkir and Yonatan Alex Arifianto, "Makna Hidup Dalam Kristus Menurut Filipi 1:21 Dan Implikasinya Bagi Orang Percaya," CARAKA: Jurnal Teologi Biblika dan Praktika 1, no. 2 (2020): 228-242.

52 Paulus Kunto Baskoro, "Prinsip-Prinsip Penggembalaan Berhati Hamba Menurut 1 Petrus 5: 2-3 Dan Implikasinya Bagi Pertumbuhan Jemaat," Veritas Lux Mea (Jurnal Teologi dan Pendidikan Kristen) 2, no. 2 (2020): 147-157.

Copyright(C2021; Ritornera - Jurnal Teologi Pentakosta Indonesia | 54
} 
membangun komunitas yang berdampak, ${ }^{53}$ bagi kemajuan bersama dan menjadi terang, garam dan berkat bagi manusia.

\section{KESIMPULAN}

Tampil dan menjadi dewasa rohani dalam Kristus, sungguh sangat penting bagi kehidupan setiap orang percaya. Kedewasaan yang dimaksud dalam bagian ini bukan fokus kepada usia yang terus bertambah, namun dalam kehidupan rohani. Salah satu bagian yang terpenting dalam kehidupan setiap orang percaya adalah ketekunan. Hidup bertekun di dalam Yesus menjadi kunci kekuatan setiap orang percaya menjalani kehidupan ini, baik tantangan ringan ataupun tantangan yang berat. Setiap persoalan, tantangan hidup, pergumulan dan problem yang dihadapi setiap orang, tidak dibatasi dengan usia, jenis kelamin, golongan strata jabatan. Siapapun bisa menghadapi tantangan dan persoalan, problemnya adalah sejauh mana respon setiap orang percaya ketika menghadapi sebuah pencobaan. Surat Yakobus 1:2-8 memberikan solusi yang luar biasa untuk orang percaya bisa menang terhadap segala tantangan hidup, yaitu dengan hidup bertekun. Tekun artinya didalam segala situasi dan keadaan orang percaya diberikan kemampuan untuk tetap bertahan dan berusaha terus tanpa putus memegang iman percaya kepada Yesus dengan menjadi pelaku Firman yang sungguh. Ini adalah sebuah gaya hidup atau sikap hidup yang tidak mudah menyerah atau kalah dalam menghadapi setiap persoalan dan pergumulan bahkan penderitaan karena mengikut Yesus. Dalam segalanya ini nama Yesus yang akan dipermuliakan.

\section{REFERENSI}

Arifianto, Yonatan Alex. “Makna Sosio-Teologis Melayani Menurut Roma 12:7.” Jurnal

${ }^{53}$ Yonatan Alex Arifianto, "Makna Sosio-Teologis Melayani Menurut Roma 12:7," Jurnal Ilmiah Religiosity Entity Humanity (JIREH) 2, no. 2 (2020): 184-197.

Copyright(C2021; Ritornera - Jurnal Teologi Pentakosta Indonesia |55 
Ilmiah Religiosity Entity Humanity (JIREH) 2, no. 2 (2020): 184-197.

Arifin, Suriani Sukowati. "Hikmat Menurut Kitab Yakobus.” Diligentia: Journal of Theology and Christian Education 1, no. 1 (2019): 15-24.

Baskoro, Paulus Kunto. "Prinsip-Prinsip Penggembalaan Berhati Hamba Menurut 1 Petrus 5: 2-3 Dan Implikasinya Bagi Pertumbuhan Jemaat.” Veritas Lux Mea (Jurnal Teologi dan Pendidikan Kristen) 2, no. 2 (2020): 147-157.

Baskoro, Paulus Kunto, and Indra Anggiriati. "Implementasi Pemuridan Dalam Efesus 4: 11-16 Bagi Pertumbuhan Rohani Jemaat Di Masa Kini.” Sabda: Jurnal Teologi Kristen 2, no. 1 (2021): 242-265.

“Keterkaitan Kedewasaan Rohani Dengan Penatalayanan Yang Maksimal Dalam Gereja Dan Dunia Market Place.” LOGIA: Jurnal Teologi Pentakosta 2, no. 2 (2021): $32-51$

Baxter, J. Sildow. Menggali Isi Alkitab. Jil. 4. Jakarta: Yayasan Komunikasi Bina Kasih/OMF, 1995.

Brown, Colin. The New International Dictionary of The New Testement Theology. Michigan: Zondervan Publishing House, 1976.

Champan, Adina. Pengantar Perjanjian Baru. Bandung: Yayasan Kalam Hidup, 2000.

Djuandy, Johan. "Revisiting the So-Called Contradiction Between James and Paul on Justification.” Jurnal Amanat Agung 13, no. 2 (2017): 243-283.

Dunnett, Walter M. Pengantar Perjanjian Baru. Malang: Gandum Mas, 2001.

Elefson, Todd. Diktat Kuliah Surat Yakobus. Yogyakarta: STT Injili Indonesia, 1997. Copyright $\bigcirc 2021$; Ritornera - Jurnal Teologi Pentakosta Indonesia |56 
Gaeblein, Frank E. The Expositors Bible Comentary. Michigan: Zondervan Publishing House, 1981.

GULO, HISKIA. “Konsep Pencobaan Menurut Yakobus 1:12-15.” BONAFIDE: Jurnal Teologi dan Pendidikan Kristen 1, no. 2 (2020): 165-179.

Guning, D.S.J.J. Tafsiran Alkitab Surat Yakobus. Jakarta: BPK Gunung Mulia, 1984.

Harianja, Sorta. "Bersukacitalah Senantiasa! Sekali Lagi Kukatakan, Bersukacitalah.” Jurnal Apollos (2017).

Humble, Kevin. Diktat Pastoral Konseling. Yogyakarta: STT Injili Indonesia, 2000.

Jansen, Irving L. James. Chicago: The Moody Bible Institude, 1971.

Jawamara, Markus Ndihi. "Memahami Konsep Iman Dan Perbuatan Menurut Yakobus: Suatu Study Eksegesis Yakobus 2:26.” Sesawi: Jurnal Teologi Dan Pendidikan Kristen 1, no. 1 (2020): 86-98.

John F. Walvoord \& Roy B. Zuck. The Bible Knowleadge Commentary. Chicago: Victor Books, 1983.

Jura, Demsy. "Mengenal Penulis Kitab Yakobus Dan Pengajarannya.” Jurnal Shanan 1, no. 1 (2017): 158-178.

Kurniawan, Jimmy. “Kajian Eksegetikal Tentang Kelahiran Baru Menurut Yohanes 3:1-8.” Jurnal Teologi Gracia Deo 1, no. 1 (2018): 1-13.

Kusradi, Sri Wahyuni. “Pengenalan Akan Nama Allah Sebagai Peneguhan Iman Dalam Masa Kesesakan.” SCRIPTA: Jurnal Teologi dan Pelayanan Kontekstual 6, no. 2 (2020): 184-204. 
Ladd, George Eldon. Teologi Perjanjian Baru, Jil. 2. Bandung: Yayasan Kalam Hidup, 1999.

Maiaweng, Peniel C D. “Kajian Biblika Tentang Pencobaan Menurut Yakobus 1: 1-18 Dan Implikasinya Dalam Kehidupan Orang Percaya.” Repository Skripsi Online 1, no. 1 (2019): 32-40.

Mantey, H.E Dana \& Julius R. A Manual Grammar of The New Testement. Toronto: Macmillan Company, 1927.

Sihaloho, Defi Ratna Sari. “Fungsi Minyak Sebagai Penyembuh (Studi Eksegetis Injil Markus 6:13 Dan Surat Yakobus 5: 14)'." Areopagus : Jurnal Pendidikan Dan Teologi Kristen 18, no. 2 (2020): 183-189.

Sihombing, S.H. M.H., Dr. Altin, and Altin Sihombing. "Keselamatan Universalisme Versus Soteriologi Kristen Dalam Perspektif Alkitab." Voice of Wesley: Jurnal Ilmiah Musik dan Agama 3, no. 2 (2020): 41-53.

Sihombing, Warseto Freddy. "Penderitaan Orang Percaya Dalam Surat 1 Petrus." KERUGMA: Jurnal Teologi dan Pendidikan Agama Kristen (2019).

Simorangkir, Sri Lina Betty Lamsihar, and Yonatan Alex Arifianto. "Makna Hidup Dalam Kristus Menurut Filipi 1:21 Dan Implikasinya Bagi Orang Percaya.” CARAKA: Jurnal Teologi Biblika dan Praktika 1, no. 2 (2020): 228-242.

Sinuraya, M.Th, Samuel Julianta. "Makna Dibenarkan Oleh Iman Dan Perbuatan Menurut Yakobus 2:14-26.” CARAKA: Jurnal Teologi Biblika dan Praktika 1, no. 2 (2020): $199-210$.

Stamps, Donald C. Alkitab Penuntun Hidup Berkelimpahan. Malang: Gandum Mas, 2000. Copyright $\bigcirc 2021$; Ritornera - Jurnal Teologi Pentakosta Indonesia |58 
Stone, Robert John. Lectures Exegetial And Pratical On The Epistle of James. Minneapolis: Klock and Clokl Christian Publishers, 1978.

Summer, Ray. Diktat Kuliah : Yang Pokok Dalam Bahasa Yunani Perjanjian. Yogyakarta: STT Injili Indonesia, 1998.

Swindoll, Charles. Maju Tiga Langkah Mundur Dua Langkah. Surabaya: YAKIN, 2000.

Tambun, Mariduk, and Adi Putra. “Kajian Teologis Terhadap Markus 10:17-27.” Jurnal Luxnos 5, no. 1 (2021): 27-36.

Tasker, RVG. The General Epistle of James. Grand Rapi. Eerdmans Publishing Company, 1956.

Tenney, Merrill C. Survei Perjanjian Baru. Malang: Gandum Mas, 1993.

Treat, Casey. Pembaharuan Pikiran. Jakarta: Yayasan Pekabaran Injil Immanuel, 1989.

Vine, W.E. An Expository Dictionary of New Testement Words. New Jersey: Old Tappan, 1980

- The Bible Self Explained A Commentary Wholy Biblical. Chicago: Moody Press, 1977.

Zaluchu, Sonny Eli. "Pola Hermenetik Sastra Hikmat Orang Ibrani.” Evangelikal: Jurnal Teologi Injili dan Pembinaan Warga Jemaat 3, no. 1 (2019): 21.

—_. "Strategi Penelitian Kualitatif Dan Kuantitatif Di Dalam Penelitian Agama." Evangelikal: Jurnal Teologi Injili dan Pembinaan Warga Jemaat 4, no. 1 (2020): 2838. 
Tafsiran Alkitab Masa Kini, Jil. 3. Jakarta: Yayasan Komunikasi Bina Kasih/OMF, 1988. 